\title{
Geotechnologies as an environmental licensing support tool in the state of Piauí, Brazil
}

Utilização de programas abertos de geotecnologia para o emprego no licenciamento ambiental no estado do

Piauí, Brasil

Bruna de Freitas Iwata ${ }^{a}$

Danielly dos Santos Ferreirab

Adriano D'Carlos Batista Oliveira ${ }^{c}$

${ }^{a}$ Doutora em Ciências do Solo pela Universidade Federal do Ceará, UFC, Professora do Instituto Federal de Educação, Ciência e Tecnologia do Piauí, IFPI, Teresina, PI, Brasil. End. Eletrônico: iwata@ifpi.edu.br

${ }^{b}$ Mestranda no Programa de Pós-Graduação em Análise e Planejamento Espacial pelo Instituto Federal de Educação, Ciência e Tecnologia do Piauí, IFPI, Teresina, PI, Brasil End. Eletrônico: danielly.santosferreira@gmail.com

'Mestrando no Programa de Pós-Graduação em Análise e Planejamento Espacial pelo Instituto Federal de Educação, Ciência e Tecnologia do Piauí, IFPI, Professor do Instituto Federal de Educação, Ciência e Tecnologia do Piauí, Teresina, PI, Brasil End. Eletrônico: adriano.dcarlos@ifpi.edu.br

doi:10.18472/SustDeb.v11n2.2020.29253

\begin{abstract}
Geotechnologies are a set of technologies geared towards collection, processing, analysis and availability of information with geographic reference. Therefore, the objective of this research is to demonstrate through the spatial analysis the environmental characteristics of an enterprise located in the municipality of Currais - $\mathrm{Pl}$, object of the environmental licensing procedure of the state competent body, using the tools of geotechnologies. The methodology consisted in using the Geographic Information System Quantum GIS (QGIS) for the creation and processing of the geographic database. Through the generation of thematic maps, it was possible to conclude that the uses of geotechnologies aid in the control and environmental monitoring, in which, it facilitates the visualization and characterization of several environmental features in the environmental licensing procedure. It was also possible to identify the areas that deserve greater attention from the environmental agency due to some damage to the environment, as well as, it assists in environmental inspection and current legislation.
\end{abstract}

Keywords: Environmental Licensing. Geotechnology. Geographic Information System.

\section{RESUMO}

As geotecnologias são um conjunto de tecnologias voltadas para coleta, processamento, análise $e$ disponibilização da informação com referência geográfica. Diante disso, o objetivo dessa pesquisa é demonstrar por meio das análises espaciais as características ambientais de um empreendimento 
localizado no município de Currais - Pl, objeto do procedimento de licenciamento ambiental do órgão competente estadual, utilizando as ferramentas das geotecnologias. A metodologia consistiu na utilização do Sistema de Informações Geográficas Quantum GIS (QGIS) para a criação e tratamento do banco de dados geográfico. Por meio da geração de mapas temáticos, foi possível concluir que as utilizações das geotecnologias auxiliam no controle e monitoramento ambiental, no qual facilita a visualização e caracterização de diversas feições ambientais no procedimento de licenciamento ambiental. Também foi possivel identificar as áreas que merecem uma maior atenção do órgão ambiental em virtude de algum dano ao meio ambiente, bem como auxilia na fiscalização ambiental e legislação vigente.

\section{Palavras-chave: Licenciamento Ambiental. Geotecnologias. Sistema de Informações Geográficas.}

\section{INTRODUCTION}

Landscapes are continually altered by human interference on the natural environment, and knowledge of the processes that occurred in the past is essential to understand the changes. The observation on land use is relevant due to the necessity to ensure sustainability facing the environmental, social, and economic issues related to it and taken to emerge in the debate on sustainable development. (LIRA; SOUTO; DUARTE, 2019).

The earth's surface is the place of different situations in terms of occupation, these come from the needs of society's production and reproduction, being modified in an abundant and fast way (LEITE et al., 2018). For meeting society's demands, vegetation is suppressed, triggered by the use of agricultural land, and if this transformation is not managed, it harms the natural conditions of the environment (PEREIRA, 2014).

In this sense, designing analyzes of the environment helps in its manipulation, enabling management and environmental planning of functionalities by the public administration as for those that come effectively from the environment (ALBUQUERQUE; SOUSA, 2019). In order to provide the management of natural resources in a sustainable manner conciliated with economic development, there is an Environmental Licensing as an instrument of inspection and control, which was established by Law No. 6,938, of August 31, 1981 (vide BRASIL, 1981) of the National Environment Policy to ensure efficient and controlled management.

Environmental licensing, discussed by Feitosa et al. (2004), is the administrative procedure whereby the competent environmental agency licenses the location, installation, expansion, and operation of companies and activities that use environmental resources considered effective or potentially polluting, or of those that, in whichever form, may cause environmental degradation, considering the legal and regulatory provisions and technical standards applicable to the case. The Government, exercising its control prerogatives, will dispatch the following licenses: Preliminary License (PL), Installation License (IL), and Operation License (OL) (CONAMA, 1997).

A preliminary license is granted in the initial planning phase of the enterprise, or activity, approving its location and conception, attesting the environmental feasibility, and establishing the basic requirements and conditions to be fulfilled in the next stages of its implementation (CONAMA, 1997). As a considerable aid to this stage, geotechnologies are diagnostic procedures for areas highlighting their respective uses, since they intend to characterize the enterprise spatially, ensuring support for the granting of the environmental license provided by the inspection agency.

Geotechnologies are characterized by equipment and methods of mathematical and computational processing. It has as principal purposes the treatment and analysis of geographic data, allowing for more specific and precise responses. Increasingly the use of geotechnologies has contributed to environmental analysis and characterization. Its utilization provides to user knowledge concerning past and current situations, besides enabling the simulation of future scenarios. Some tools widely utilized in geotechnology are Geographic Information Systems (GIS), remote sensing, and GPS (Global Positioning System) (MENDES, 2019). 
GIS is a computer-assisted system that can insert, analyze, and display geographically referenced information useful for environmental management (SUBRAMANI; VENKATACHALA; PRIYANKA, 2017). One of the most important roots of GIS is the automated cartographic workflows, with the additional objective of integrating and analyzing geospatial information (JONES, 2013).

According to Mendonça et al. (2011, p. 9), Remote Sensing is a science used to detect objects without direct contact with them. The physical properties of the interaction of electromagnetic energy make it possible to characterize such objects. This thematic plurality towards which the use of Geotechnologies has converged comes from different theoretical and methodological matrices, especially the integrative approaches that seek to analyze the Society-Nature relationship (SILVA; ROCHA; AQUINO, 2017).

The main intention of using geotechnologies in environmental monitoring is to contribute efficiently so that production in the licensed area occurs sustainably. Thus, the use of these tools has fundamental importance for the processing and generation of information in reports and maps, aside from being suitable for providing and synthesizing information for the environmental study (SOBRAL et al., 2017). These mappings influence the speed of inspection and, consequently, compliance with relevant laws (LUPPI et al., 2015).

Mapping, which is used within Geoprocessing techniques (Rocha, 2000, Fitz, 2008), is an effective way of analyzing and visualizing data. Conceived of Kerski (2015) as one of the five converging global trends within geographic research, Geotechnologies have found extensive application, granting to map and analyze a large variety of phenomena, with unprecedented speed and precision. This may also be found in Fitz (2008) and Medeiros (2011).

Based on the previously mentioned, this study aimed to present, through a case study of rural property, in the state of Piauí, how the geotechnologies would help the public environmental manager on the characterization and monitoring of the enterprise that desires to apply for the environmental license.

\section{MATERIALS AND METHODS}

In order to carry out this work, an enterprise from the State of Piauí was used to exemplify the study, which required a Preliminary License (PL) of the establishment from the environmental agency. Data necessary for the analysis of the project and its environmental characteristics to conclude the record have been obtained by the Geoprocessing sector belonging to the Land and Environmental Geotechnology Center (Portuguese acronym, CGEO) of the Secretariat for the Environment and Water Resources of the State of Piauí (Portuguese acronym, SEMAR/PI), which has a data bank containing information on hydrography, biome, vegetation, and other items that provide a spatial visualization of the property, facilitating the making of some decisions by the auditors and environmental managers.

In this research, the free version of QUANTUM GIS (QGIS) 2.14 software was used to create the geographic database. In which the files of the property were inserted in the shapefile format with the following features: property area, PPA (permanent protection area), legal reserve and intervention area, all in the SIRGAS 2000 projection system and with the UTM (Universal Transverse Mercator) as a function of property location (23 or 24$)$.

Posteriorly, data processing was carried out integrating the spatial information from the archives of SEMAR/PI and other official sources such as the Brazilian Institute of Geography and Statistics (Portuguese acronym, IBGE), National Water Agency of Brazil (Portuguese acronym, ANA), and the National Rural Environmental Registry System of Brazil (Portuguese acronym, SICAR). After the spatial analysis, it is possible to overlay the georeferenced information of the property area with the official available databases and satellite images. 
The free satellite image used was that of the SENTINEL-2A satellite, acquired on 24 June 2017, with a spatial resolution of 10 meters, scene T23 LNL available on the website https://earthexplorer.usgs.gov/. For the classification of the true image, the bands 4,3,2 RGB Red (red) Green (green) Blue (blue) were used in the QGIS software. For analyzing an environmental licensing process, the following activities are usually carried out, which vary from case to case:

a. download satellite images,

b. treatment and classification of downloaded images;

c. overlapping of the process files with the CGEO base;

d. pre-analysis of the rural environmental registry (RER) of the property, etc.

For issuing the technical report on Geoprocessing, the Microsoft Office Word text editor and the Microsoft Office Excel spreadsheet editor were used, both present in the Microsoft Office 2003 package.

The digital cartographic bases used were acquired from IBGE, ANA, Chico Mendes Institute for Biodiversity Conservation (ICMBIO), Ministry of the Environment (MMA), and SICAR in shapefile format, where elements such as those shown in the table below are selected.

Table 1 | Bases used in the construction of the SEMAR/PI technical report on Geoprocessing.

\begin{tabular}{|c|c|c|c|c|c|c|c|}
\hline \multirow{2}{*}{\multicolumn{2}{|c|}{ FEATURE }} & \multicolumn{2}{|c|}{ Digital Archive (A) } & \multicolumn{2}{|c|}{ Reference Document (B) } & \multirow{2}{*}{$\begin{array}{c}\text { Difference } \\
\text { ha }\end{array}$} & \multirow{2}{*}{$\begin{array}{c}\text { CAR } \\
h a\end{array}$} \\
\hline & & ha & $\%$ & ha & $\%$ & & \\
\hline a) & TOTAL AREA & & & & & & $67,112.33$ \\
\hline b) & PPA & & & & & & $1,278.85$ \\
\hline c) & LEGAL RESERVE & & & & & & $2,1080.17$ \\
\hline d) & AREA FOR DEFORESTATION & & & & & & \\
\hline e) & DEFORESTED AREA & & & & & & \\
\hline f) & $\begin{array}{l}\text { REMNANT NATIVE } \\
\text { VEGETATION }\end{array}$ & & & & & & $21,031.17$ \\
\hline g) & CONSOLIDATED AREA & & & & & & $46,031.44$ \\
\hline & TOTAL & 0,00 & $0 \%$ & 0,00 & $0 \%$ & 0,00 & \\
\hline
\end{tabular}

Source: Centro de Geotecnologia Fundiária e Ambiental do Piauí (2018).

In addition to the digital files, the entrepreneur must present, at the beginning of the environmental licensing process, the Georeferenced Property Plant, and the RER receipt for the property. By this information, a spreadsheet is created comparing the values of the enterprise's features in the three files: Digital media in shapefile format, Georeferenced property plan, and what was declared in SICAR, according to the model in the table below. 
Table 2 | Area chart used in the construction of SEMAR/PI Geoprocessing technical report.

\begin{tabular}{|c|c|}
\hline LAYER & SOURCE \\
\hline COUNTY & IBGE 2018 \\
\hline WATERCOURSE & \\
\hline PROPERTY & \\
\hline Legal Reserve & \\
\hline Property area 2017 \\
\hline Intervention area 2018 \\
\hline Permanent protection area (PPA) \\
\hline IMAGEM SENTINEL 2017 \\
\hline
\end{tabular}

Source: Piauí Land and Environmental Geotechnology Center (2018).

The area calculation was done in the Quantum GIS software, and the opinion was filled out by analyzing this documentation and files presented.

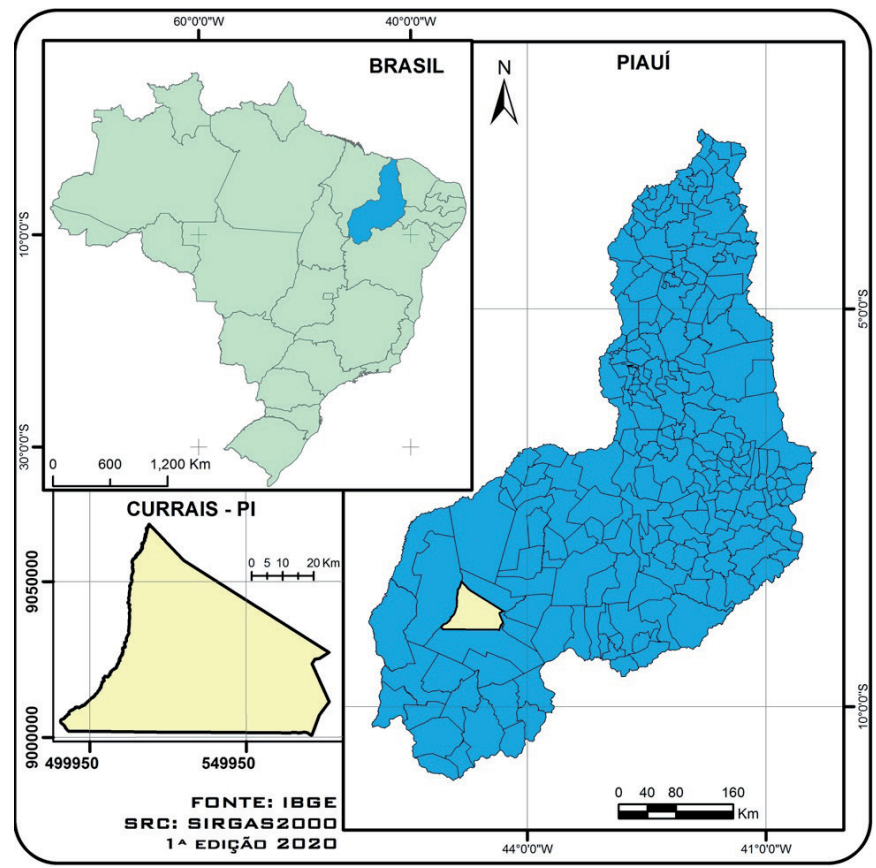

Figure 1 | Location Map of Brazil highlighting the state of Piauí and the municipality of Currais.

Source: Oliveira (2018).

\section{RESULTS AND DISCUSSIONS}

The maps generation of the environmental characteristics of the rural property by geotechnologies showed, above all, the study area has its legal reserve fragmented into three distinct parts within the property, which does not represent an ecological corridor, and also, the existence of occupations in the east portion of the legal reserve area of the enterprise was verified, as well as possible Permanent Preservation Areas (PPA's) not declared by the owner. Such observations were made possible based on the spatial analysis tools that provide substantial subsidies to environmental planning, from the perspective of mitigating the intense process of use and occupation in areas of recognized fragility and environmental vulnerability (SILVA; ROCHA; AQUINO, 2017).

According to Piauí State Law No. 6,947 of 01/09/2017 (Piauí, 2017), which deals with the criteria and regulations of State environmental licensing, in the licensing stage, an analysis of the Geoprocessing 
sector is held. Thus, it is established the approval of the intended area for enterprise implementation based on spatial analysis using geotechnologies and respecting legal and environmental restrictions.

The results generated in the Geoprocessing report are obtained with the data of the property overlaid with other official bases of the sector (water resources, biomes, among others). Thus, it possible to get an expanded and grounded view of the situation from the integration of different georeferenced parameters. Based on the use of these methodologies, it could be developed an available database; elaboration of diagnoses; in addition to contributing to the planning and orientation of public policies and environmental actions in the regions, among others (MENDES,2019).

In this case study, environmental licensing in the State of Piauí follows an analysis flowchart and criteria according to a database containing the geospatial information of the property with all its attributes. Through geographic database verification, at QGIS, they made it possible to identify whether the data declared by the entrepreneur were in accordance with the official bases of SEMAR/PI. Furthermore, it was possible to easily visualize the spatial distribution of the legal reserve corridor proposed by the developer compared to neighboring properties using the SICAR base. It was also possible to verify if all the PPA's of the enterprise were declared.

Through the spatial visualization of the real estate information on the maps, SEMAR/PI environmental auditors and managers, when issuing an environmental license, the agility, and efficiency in technical reports become more agile. The results obtained show the state of preservation of the legal reserve and PPA of rivers and streams.

According to the routine of data verification and information to be compiled during the spatial analysis at QGIS, thematic maps are generated on the environmental characteristics of rural properties, with a certain level of details, enabling a more reliable and efficient environmental assessment.

Figure 2 presents the general view of the project according to what has been informed by the owner. Therefore, it is possible to see that the property's legal reserve is fragmented into three areas and that the sum of them corresponds to the minimum percentage required for the biome relative to the property.

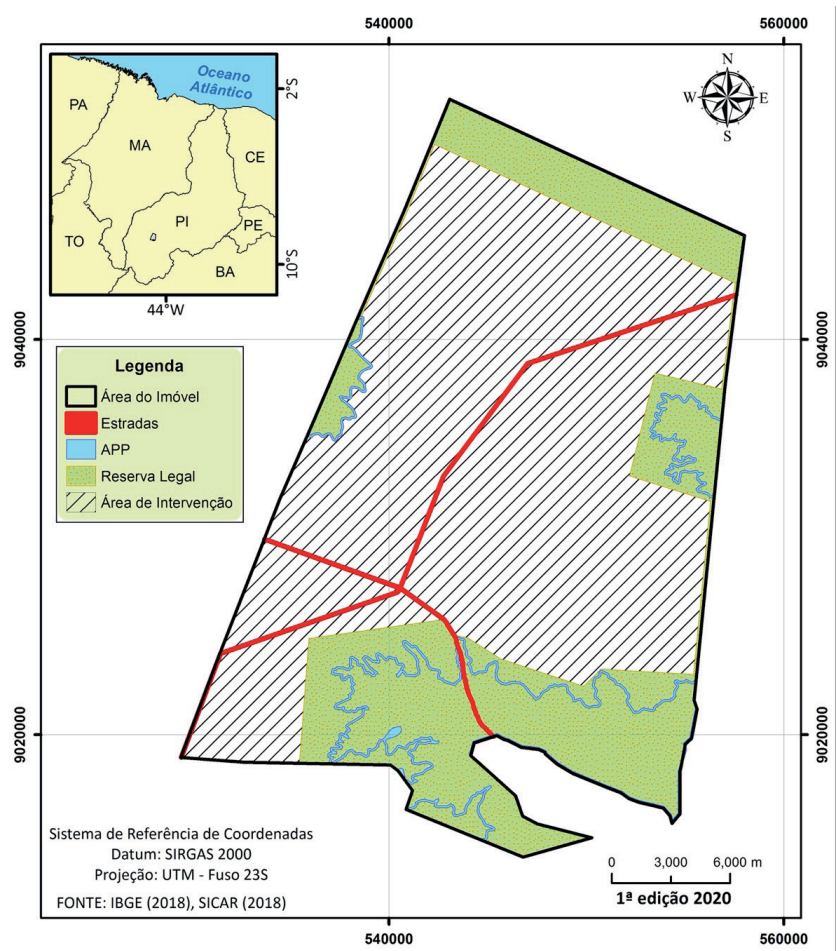

Figure 2 | Thematic map representing the features of the property under study.

Source: Ferreira (2018). 
Figure 3 shows the satellite image SENTINEL 2A with the features of the area under study. Through the images, it is seen to verify possible occupations in the legal reserve area of the eastern portion of the project, as well as to verify possible areas of PPA. LRs (Legal Reserves) have as the main function to ensure the differentiated ecological role in the distinct Brazilian biomes and also have an important role in the water infiltration into the soil, as this process favors the recharge of the aquifer (PEREIRA, et al, 2017).

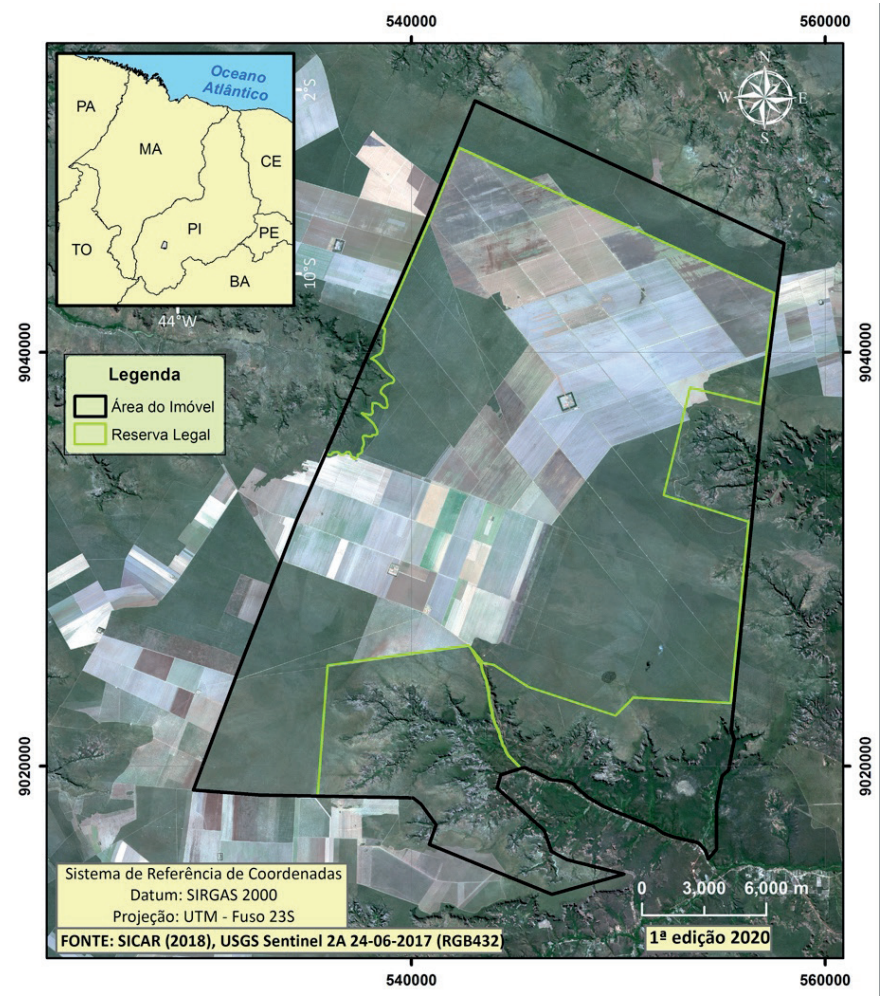

Figure 3 | Thematic map of the property's features and the satellite image SENTINEL 2A (06/24/2017).

Source: Ferreira (2018).

In figure 4, through the satellite images, it is verified possible occupations in the legal reserve and PPA area of the enterprise under study, which is not allowed according to the law. The detail level with the monitoring of on-site inspection points favors environmental inspection and monitoring.

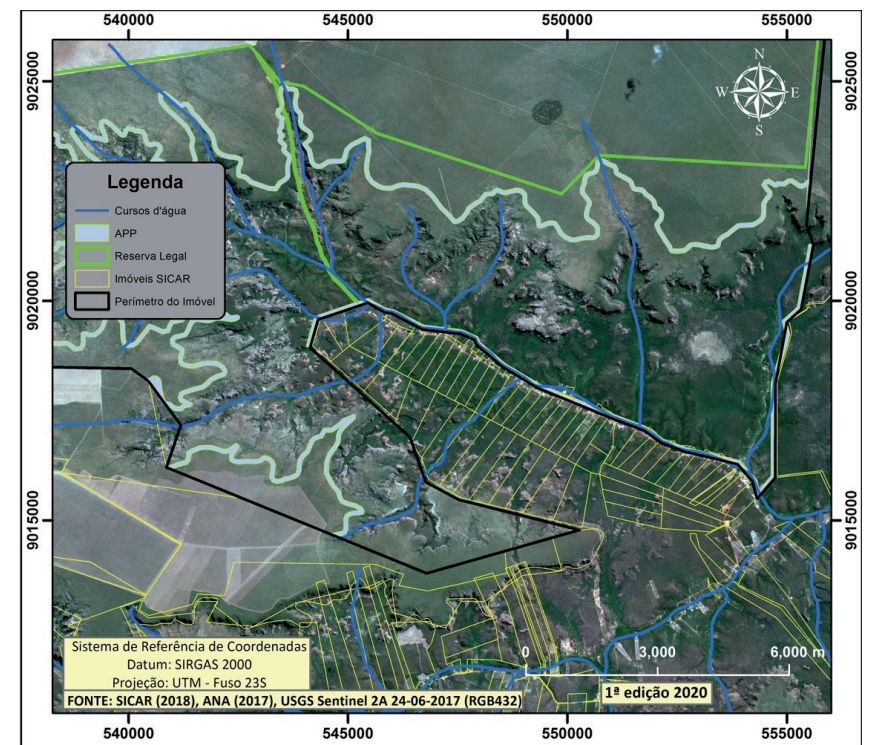

Figure 4 | Occupations in the areas of PPA and Legal Reserve of the property. Source: Ferreira (2018). 
In figure 5, it is possible to identify the properties registered in the SICAR base (Oct/2018) that are in overlap with the studied legal reserve area. In this sense, geotechnologies play a significant role in aggregating diverse and multiple data from various platforms, generating information with clarity and integration.

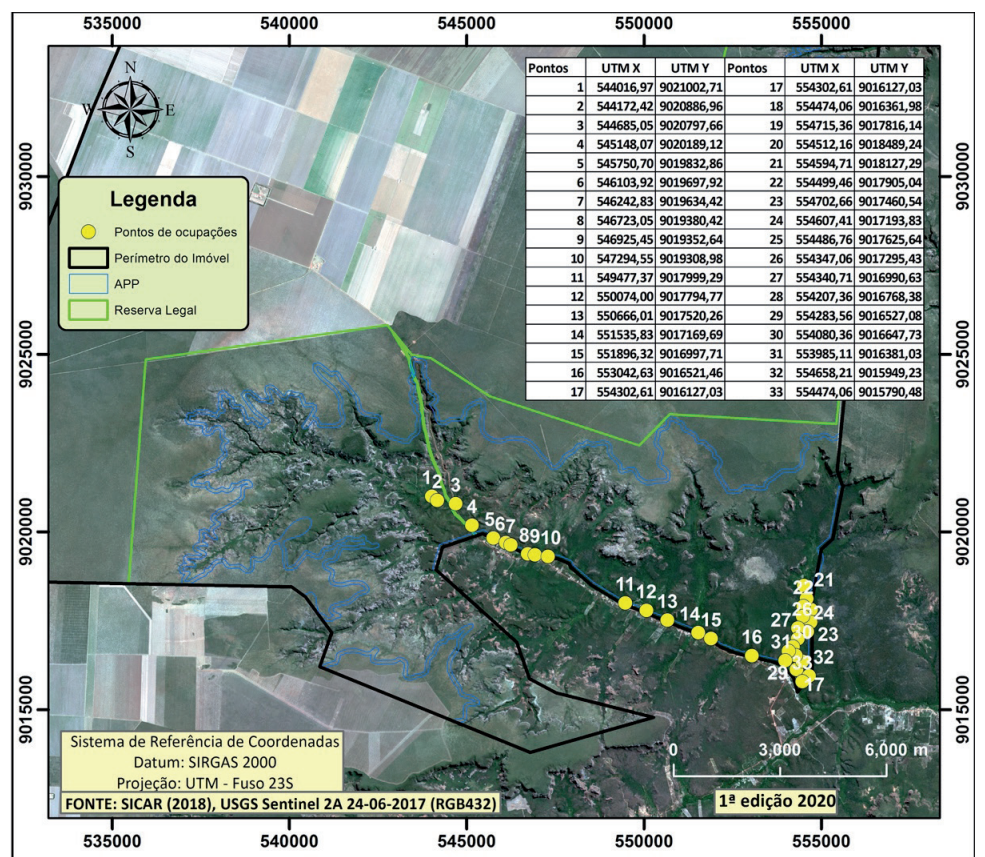

Figure 5 | Properties registered with SICAR in overlap with the Legal Reserve. Source: Ferreira (2018).

In figure 6, it is possible to verify that all PPA's were declared by the owner in SICAR, by overlapping with the official watercourse base of ANA 2017. Environmental auditors also do the verification on the field, however, due to the large area, this is sometimes impossible. And through geotechnologies, this verification may be conducted in an agile, fast, and efficient way. PPA's are essential for the prevention of negative anthropic impacts on water resources and erosion dynamics. In this sense, it is essential to characterize the riverside forest structure in order to a better understanding of its functions, as suggested by Pereira et al. (2017).

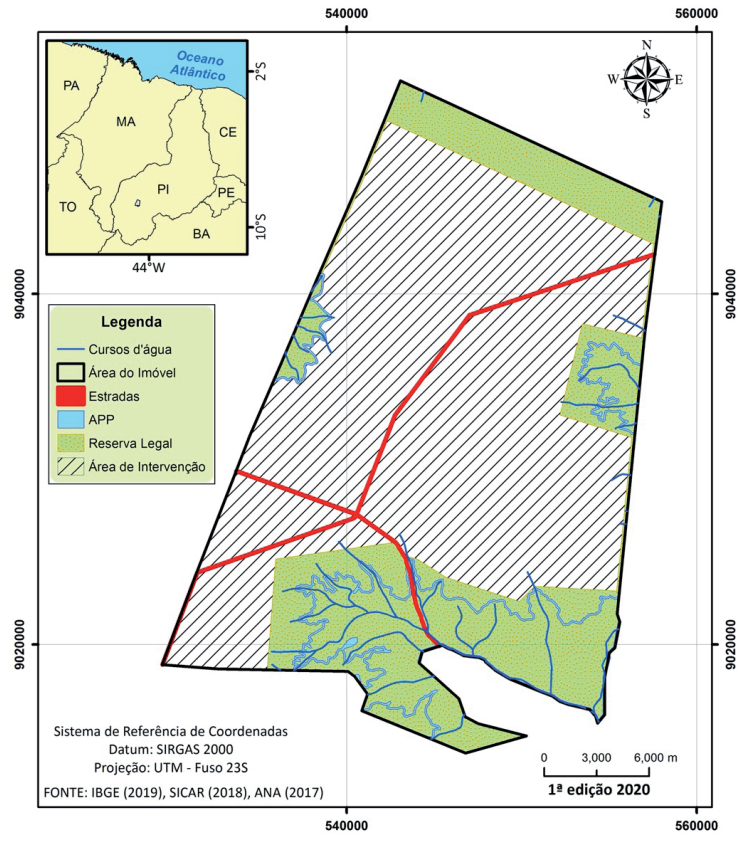

Figure 6 | Watercourses, ANA 2017.

Source: Ferreira (2018). 
Given all the mapping of the case under study, geotechnologies applied to environmental licensing help to reduce costs, considering that several analyzes of the property may be performed through satellite images and data integration, thus generating more accessibility information and data accuracy.

\section{FINAL CONSIDERATIONS}

This study has been provided the identification of areas susceptible to the process of environmental degradation associated with human activities through geotechnologies, as they deserve greater attention from the environmental agency, as well as assisting in environmental inspection and compliance with current legislation. The characterization of the rural property by this methodology facilitates the control and monitoring of preserved areas with vegetation linked to the substitution by economic activities without the proper environmental license.

The georeferenced data in the GIS environment facilitate the storage, manipulation, consultation, evaluation, spatial view, and analysis of the mapped information. At SEMAR/PI, the GIS is used in the daily environmental licensing, being useful mainly in environmental monitoring, enabling quality in the analysis, as well as a broad spatial view of the territory, which makes it essential for the inspection and preservation of environmental resources.

Given this, the GIS tool becomes essential in the analysis of projects, besides serving as a basis for strengthening the inspection of already consolidated projects, observing that they continue to obey the standards of the legislation. It is worth mentioning that in addition to the employment of open programs, such as QGIS and GVSIG, the use of these tools can be associated with the use of flight execution technologies with unmanned aerial vehicle (UAV), such as those with fixed-wing (large and medium properties), or drones (small and medium properties).

In this sense, geotechnologies become an important tool to be used in environmental studies since these techniques set has allowed to quickly and effectively identify the environmental status of the spatial elements of a given territory. Thus, it makes it possible to carry out the integration of the spatial elements from different sources, to determine the sustainable use of the land, and to ensure more efficiency and reliability in the decision making of the public environmental manager.

\section{REFERENCES}

AGÊNCIA NACIONAL DE ÁGUAS. Base Hidrográfica Ottocodificada Multiescalas 2017 (BHO 2017). Disponível em: <https://metadados.ana.gov.br/geonetwork/srv/pt/main.home>. Acesso em: 22 set. 2018.

ALBUQUERQUE, D. S.; SOUSA, M. R. M. Análise Geoambiental como subsídio ao Planejamento no município de Pereiro/Ceará/Brasil. Revista Equador, v. 8, n. 2, p. 348-364. Universidade Federal do Piauí. Disponível em: <http://www.ojs.ufpi.br/index.php/equador>. Acesso em: 22 set. 2018.

BRASIL. Conselho Nacional do Meio Ambiente. Resolução n. 237, de 22 de dezembro de 1997. Regulamenta os aspectos de licenciamento ambiental estabelecidos na Política Nacional do Meio Ambiente. Diário Oficial [da] República Federativa do Brasil, Brasília, DF, 22 dez. 1997. Disponível em: <http://www.planalto.gov.br/>. Acesso em: 22 set. 2018.

BRASIL. Lei no. 6.938, de 31 de agosto de 1981. Dispõe sobre a Política Nacional do Meio Ambiente, seus fins e mecanismos de formulação e aplicação, e dá outras providências. Diário Oficial da República Federativa do Brasil, Brasília, DF, 2 de setembro de 1981. Disponível em: <http://www.planalto.gov.br/>. Acesso em: 22 set. 2018.

BRASIL. Ministério do Meio Ambiente. Programa Nacional de Capacitação de gestores ambientais: licenciamento ambiental. Ministério do Meio Ambiente. Brasília: MMA, 2009. 
CAMARA, G.; DAVIS, C. Introdução à Ciência da Geoinformação. São José dos Campos, INPE, 2004 (Cap. 01). Disponível em: <http://www.dpi.inpe.br/gilberto/livro/introd/cap1-introdução.pdf>. Acesso em: 23 set. 2018.

FEITOSA, I. R.; LIMA, L. S.; FAGUNDES, R. L. Manual de Licenciamento ambiental: guia de procedimento passo a passo. Rio de Janeiro: GMA, 2004.

FITZ, P. R. Geoprocessamento sem complicação. São Paulo, SP: Oficina de Texto. 2008.

INSTITUTO BRASILEIRO DE GEOGRAFIA E ESTATÍSTICA. Malha municipal. 2006. Disponível em: <https://www. ibge.gov.br/geociencias/organizacao-do-territorio/15774-malhas>. Acesso em: 22 set. 2018.

JONES, C. Geographical information systems and computer cartography. 2. ed. New York: Routledge. Taylor \& Francis. 2013.

LEITE, M. E. et al. Geotecnologias aplicadas à estimativa da temperatura de superfície em diferentes usos e ocupações do solo na Área de Proteção Ambiental do Rio Pandeiros - Minas Gerais. Caderno de Geografia, [s.l.], v. 28, n. 53, p. 490-509, 12 maio 2018. Pontifícia Universidade Católica de Minas Gerais.

LIRA, M. V.; SOUTO, M. V. S.; DUARTE, C. R. Multitemporal Analysis of the Landscape Dynamics for the Municipalities of Barroquinha and Chaval, Northwest of the State of Ceará - Brazil, for Land Use and Coverage. Anuário do Instituto de Geociências - UFRJ, [s.I.], v. 42, n. 1, p. 471-482, 13 maio 2019. Instituto de Geociências - UFRJ.

LUPPI, A. S. L. et al. Utilização de Geotecnologia para o Mapeamento de Áreas de Preservação Permanente no Município de João Neiva, ES. Floresta e Ambiente, Seropédica, v. 22, n. 1, p. 13-22, mar. 2015. Disponível em: <http://www.scielo.br/scielo.php?script=sci_arttext\&pid=S217980872015000100013\&lng=en\&nrm=iso>. Acesso em: 10 out. 2018.

MEDEIROS, A. Norteando seus conhecimentos sobre Geotecnologias. Disponível em: <http://andersonmedeiros. com/norteando-seusconhecimentos-sobre-geotecnologias/2011>. Acesso em: 24 out. 2018.

MENDES, I. A. S. O Uso de Geotecnologias na Organização do Espaço. Cadernos do Leste, v. 19, n. $19,2019$. Universidade Federal de Minas Gerais. Belo Horizonte. Disponível em: <https://periodicos.ufmg.br/index.php/ caderleste/article/view/13157/10398>. Acesso em: 11 out. 2018.

MENDONÇA, R. A. M. et al. Uso das Geotecnologias para Gestão Ambiental: experiências na Amazônia Meridional. Disponível em: <http://www.icv.org.br/wp-content/uploads/2013/08/uso-das-geocnologias-paragest\%C3\%A3oambiental.pdf>. Acesso em: 24 out. 2018.

PEREIRA, C. C. Temperatura de Superfície na Bacia da Usina Hidrelétrica (UHE) Barra dos Coqueiros, utilizando climatologia e sensoriamento remoto. Goiás. 2014. Dissertação (Mestrado em Geografia) - Universidade Federal de Goiás. 2014.

PEREIRA, D. G. S. P. et al. Environmental Protection Areas: the case of the Bebedouro Stream Watershed. Ambiente \& Sociedade, [s.I.], v. 20, n. 1, p. 105-126, mar. 2017. FapUNIFESP (SciELO).

PIAUÍ. Lei estadual № 6.947, de 09 de janeiro de 2017. Dispõe sobre as diretrizes do licenciamento ambiental estadual, estabelece os prazos e procedimentos para a emissão de licenças, declarações e autorizações ambientais e dá outras providências. Disponível em: <https://www.legisweb.com.br/legislacao/?id=335723>. Acesso em: 23 set. 2018.

QGIS. Sistema de Informação Geográfica QGIS versão 2.14. Projeto da Fundação Geoespacial de Código Aberto. Disponível em: <http://qgis.osgeo.org>. Acesso em: 14 out. 2018.

ROCHA, C. H. B. Geoprocessamento: tecnologia transdisciplinar - Juiz de Fora, MG: Ed do Autor, 2000.

SILVA, F. J. L. T. da.; ROCHA, D. F.; AQUINO, C. M. S. de. Geografia, Geotecnologias e as novas Tendências da Geoinformação: indicação de estudos realizados na Região Nordeste. Interespaço - Revista de Geografia e Interdisciplinaridade, [s.I.], v. 2, n. 6, p. 176-197, 9 mar. 2017. Universidade Federal do Maranhão.

SISTEMA NACIONAL DE CADASTRO AMBIENTAL RURAL. Disponível em: <http://www.car.gov.br/\#/sobre>. Acesso em: 22 set. 2018. 
SOBRAL, M. do C. et al. Geotecnologias na gestão de reservatórios: uma revisão e uma proposta de integração. Eng. Sanit. Ambient., Rio de Janeiro, v. 22, n. 5, p. 841-852, Oct. 2017. Disponível em: <http://www.scielo.br/ scielo.php?script=sci_arttext\&pid=S141341522017000500841\&Ing=en\&nrm=iso>. Acesso em: 24 out. 2018.

SUBRANI, T.; VENKATACHALA, K. K. M.; PRIYANKA, S. Assessment Of Impact On Aquaculture Using Remote Sensing Data And Gis In Tiruchendur. International Journal of Emerging Trends \& Technology in Computer Science (IJETTCS), v. 6, n. 3, May-June 2017, p. 157-166, ISSN 2278-6856.

UNITED STATES GEOLOGICAL SURVEY. Earth Explorer. Sentinel 2A S2A_MSIL1C_20170624T132231_N0205_R038_ T23LNL_20170624T132231.SAFE. Data da imagem: 24 de junho de 2017. Disponível em: <https://earthexplorer. usgs.gov/>. Acesso em: 20 set. 2018. 